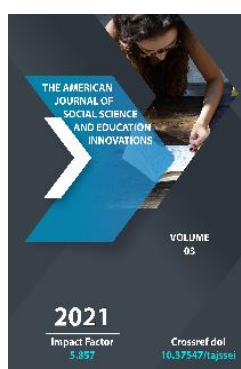

Journal Website: http://usajournalshub.c om/index,php/tajssei

Copyright: Original content from this work may be used under the terms of the creative commons attributes 4.0 licence.

\section{Teaching English In A Credit System}

\author{
Ibragimova Shaxnoza Tursunovna \\ Lecturer Teacher, Tashkent University Of Information Technologies Named After Muhammad \\ Al-Khwarizmi, Uzbekistan
}

\section{Abduraxmonova Mavluda Sodiqovna}

Lecturer Teacher, Tashkent University Of Information Technologies Named After Muhammad Al-Khwarizmi, Uzbekistan

\section{Xakimova Laziza Yusupovna}

Assistant, Tashkent University Of Information Technologies Named After Muhammad AlKhwarizmi, Uzbekistan

\title{
ABSTRACT
}

Credit-modular training system is a model of the organization of the educational process, which is based on the combination of muzzle training technologies and credits educational units. The following article looks into educating foreign languages in higher education in credit module system.

\section{KEYWORDS}

Module system, credit, gradual transition of the educational process, higher education

\section{INTRODUCTION}

The decree "On approval of the Concept of development of the higher education system of the Republic of Uzbekistan until 2030" signed by Shavkat Mirziyoyev on October8, 2020 states that Symonds World University Rankings, Times Nigher Education or Academic Ranking of World Universities) in the list of the top 1,000 higher education institutions and the gradual transition of the educational process in higher education institutions to the creditmodule system "transfer" was marked.

The credit-module system is a process of organizing education, which is a model of 
assessment based on a set of modular technologies of teaching and credit. Carrying it as a whole is a multifaceted and complex systemic process. The credit-module principle focuses on two main issues: ensuring the independent work of students; assessment of students' knowledge on the basis of ratings.

The main tasks of the credit-module system are:

Modular organization of educational processes;

Determine the value of a single subject, course (credit);

Assessment of students' knowledge on the basis of rating points;

Allow students to create their own curricula individually;

Increase the share of independent learning in the educational process;

Ease of training programs and the possibility of change depending on the demand for specialists in the labor market.

The above is not only to teach on the basis of innovative educational technologies, but also to learn independently from the student, to take a new approach to education, to acquire the necessary and in-depth theoretical knowledge based on the demands of the labor market, training to form practical skills. In short, the system is focused on the professional development and maturity of the student. It is aimed at ensuring the lifelong learning of the scientist and the formation of human capital that can meet the requirements of the labor market and modernity.

A module is a part of a curriculum that covers several subjects and courses. It is a set of several disciplines (courses) aimed at developing students' knowledge and skills, the ability to think analytically and logically. The teacher organizes the learning process, gives live, video and audio lectures, coordinates and monitors the student's activities. The student will study the topic independently and complete the assignments.

According to foreign experience, the educational process in the credit-module system consists of 2-4 modules per semester. The disciplines summarized in the module are easily formed from complex theoretical to practical sciences and on the principle of logical complementarity. In order to become a professional, a student needs not only information, but also the ability to process it and put it into practice.

Module-based curricula are developed on a case-by-case basis and include:

Full disclosure of learning objectives and tasks;

Requirements for the student's qualifications to be acquired at the beginning and end of the subject (course);

A summary (syllabus) of each subject included in the module, ie topics of lectures, plans of seminars and practical exercises, assignments for the assessment of independent learning;

Summary of teaching: methods and tools of teaching; methods and forms of knowledge assessment.

The module-based system uses a rating system to assess students' knowledge, skills and abilities. It assesses all of a student's learning activities, including in-class and out-ofclassroom learning. 
Credit is a measure of the student's workload (time) spent studying and mastering a subject in a particular field of study or program (course). A credit is a minimum amount of time set by a student for a normative document, usually one week for classroom and independent study. Credit is given to a student after completing the assignments in a particular subject and passing the final exam.

Each student must collect credits in order to receive a diploma in their chosen field and specialty in the future. Accumulated credit will help the student to improve his / her skills or get additional higher education throughout his / her life. In economic terms, accumulated credit becomes a student's academic "asset."

Credit technology gives learners the right to choose the elective subjects included in the working curriculum, thereby directly participating in the formation of an individual curriculum. They are given the freedom to choose not only the subjects but also the professors. Giving students the opportunity to choose subjects is a positive thing. It is also a measure of the value of learning.

Credit-modular system training the topic provides for the organization of assimilation students of educational material in the disconfidential mode according to a previously developed modular program, which consists of logically completed parts of the educational material (modules) with structural content each module and grading system knowledge of students.

The credit-modular system has its own advantages and is considered as a means in increasing the mobility of students when moving from one curriculum to another, including postgraduate programs education. Credit-modular system the topic enables students to choose host for learning and assimilation necessary number of academic disciplines, take obligations instructions for their assimilation during the course of idle time. The credit-modular system provideslooks at:

- Modular structure of educational program;

- Use credits units (credits) to assess the labor intensity;

- The use of point-rating knowledge assessment systems;

- Participation of students in the formation research institute of an individual curriculum;

- An increase in the share of self-learning in education educational process;

- Increasing the flexibility of the educational programs.

The fundamental differences between the modular learning from other types of training concluded are in the following positions:

- Training content is presented in complete, independent, complex modules that are at the same time information bank and methodological guide guidance on its assimilation;

- Interaction of the teacher and the teaching in the educational process is carried out on fundamentally different basis - with the help of muzzle provides a conscious selfthe definitive achievement of students lone level of preliminary training loyalty to every pedagogical meeting;

- The very essence of modular training requires the inevitable adherence to priority subject-subject relationship between do teacher and students in the educational process. 
Foreign language teaching based on creditmodular system has its own specificity. Language teaching is practical. tied character, discipline "Foreign strange language "is multidimensional, that is, it includes not only teaching lectures sike, but also other aspects of the language, as well as types of speech activity. You also need to remember that all students have different levels of language proficiency. As a trace- is one of the features of teaching foreign strange language with creditmodular system is the presence of multilevel control concerns. In the future, students can independently adjust the level and speed the rate of assimilation of the material. Although the module provides for various different types and forms of educational activities, when teaching a foreign language accent shifted to practical training. Availability compulsory homework is also is one of the features. Homemade the task is checked by the teacher of choice randomly or in a group in class. When teaching a foreign language, you can it is more expedient to divide the blowing into introductory, basic and additional. In this case, the input this module contains mandatory test determination of the level of "residual" knowledge. The basic module defines the knowledge, skills and abilities that are required shape or fix. For every the student receives a certain amount of number of points. Points are accumulated for homework, for dictations on the vocabulary of the current lesson and topic, for narration of the text, drawing up dialogues and conversation on the topic under study and writing a test work.

The additional module includes for the performance and protection of design work, writing essays, completing additional exercise. Talking about the credit modular system learning a foreign language, you must mention the point-rating system evaluation. Pointrating assessment system knowledge provides a 100-point scale, i.e. 100 points is the maximum number of the number of points that students can receive for academic success in the process All study of the content module. Estimated knowledge for a meaningful module is taken into account evaluates the grades received for all types of tests day classes, for the current and final test testing (for example, for doing practice chemical, laboratory studies, etc.) with volume of weighting factors. Total estimate learning the assimilation of educational material discipline Pliny is determined without a semester the level examination as an integrated assessment assimilation of all meaningful modules with taking into account the weight coefficients.

The point-rating system is designed meant to increase objectivity and the reliability of the assessment of the level of training, is one of the controls for quality of education. Point-rating system for assessing Allows learners to: understand the system formation of assessments in disciplines and other types of employment in order to obtain final assessments; realize the need systematic work to implement curriculum based on knowledge of their current rating score for each discipline and its change due to untimely better mastering of the material; timely assess thread the state of your study work discipline, performance of all types of educational load before the start of the control and a fatal period; during the whole period training to make adjustments to the organization of current independent work.

\section{REFERENCES}

1. Acxiom Corporation (2011). Experiences verifying the identity of online students. 
Acziom Corporation. Al-Ajlouni, K. I. (2015). Learning Effects of Using Learning Management System (Moodle) by Students of Arab Open University. Pp.1540.

2. Proceedings of MAC-ETel 2015. Multidisciplinary Academic Conference on Education, Teaching and E-Learning, Prague. Al-Amleh, M. (2014). Identifying the Palestinian Culture According To Hofstede's Theory. MA thesis, Jerusalem, occupied Palestinian Territories: Al-Quds University. Alkailani, M., Azzam, I. A., \& Athamneh, A. B. (2012). Replicating Hofstede in Jordan: ungeneralized, reevaluating the Jordanian culture. International Business Research, 5 (4), p.71.

3. American University in Cairo News (2015) Faculty Reform Requires Change in the Mindset of Educators, Youth [Online], Cairo. Available at: http://www.aucegypt.edu/news/stories/fa culty-reform-requireschange-mindseteducators-youth (Accessed 27/11/2017) Assaad, R., Salehi-Isfahani, D., \& Hendy, R. (2014). Inequality of opportunity in educational attainment in Middle East and North Africa: evidence from household surveys. In Economic Research Forum Working Paper Series No (Vol. 834). 